\title{
Carcinoma in Situ of the Eye in a Developing Community
}

\author{
Wilson IB Onuigbo ${ }^{1 *}$ and Nwabueze 0 Magulike ${ }^{2}$ \\ ${ }^{1}$ Department of Pathology, The University of Nigeria Teaching Hospital, Nigeria \\ ${ }^{2}$ Department of Ophthalmology, The University of Nigeria Teaching Hospital, Nigeria
}

Submission: June 12, 2018; Published: July 03, 2018

*Correspondence Address: Wilson IB Onuigbo, Department of Pathology, The University of Nigeria Teaching Hospital, Enugu 400001,

Nigeria, Email: wilson.onuigbo@gmail.com

Abstract

German authors stressed that carcinoma in situ is part of a pathological entity that is rare. From Argentina, cases of this growth were presented recently. Therefore, the purpose of this paper is to present 5 cases from the Igbo ethnic group in Nigeria. It is shown, by way of comparison that Igbo patients do not present early for the treatment of their malignant eye condition. It is hypothesized that the ratio of (i) in situ cases to (ii) full blown cases is indicative of the degree of awareness of malignant eye disease among a community.

Keywords: Eye;Tumor;Carcinoma in situ; Squamous carcinoma; Awareness; Igbos

\section{Introduction}

German authors wrote that "Carcinoma in situ of the cornea is part of a pathological entity, which covers all conjunctival and corneal epithelial neoplasm (CIN)," adding that it is rare [1]. On their part, Argentinan associates contributed a series of 4 cases consisting of two men and two women of average age 53.2 (range 39-71) years [2]. Therefore, the purpose of this paper is to present 5 cases from Nigeria. This should facilitate comparison with the data in the literature.

\section{Investigation}

According to a Birmingham (UK) group [3], the establishment of a histopathology data pool improves epidemiological analysis. Now, such a data pool serves the Igbo ethnic group [4]. Therefore, the records were searched in respect of this developing community with reference to carcinoma in situ and squamous carcinoma proper.

\section{Results}

Table 1: Epidemiological data from a developing community.

\begin{tabular}{|c|c|c|c|c|c|}
\hline No & Initials & Age & Sex & Side & $\begin{array}{c}\text { Provisional } \\
\text { Diagnosis }\end{array}$ \\
\hline 1 & OE & 50 & F & R & Melanosis bulbi \\
\hline 2 & OC & 38 & F & R & Squamous carcinoma \\
\hline 3 & UK & 64 & F & R & Bowen's disease \\
\hline 4 & CO & 28 & F & L & Growth \\
\hline 5 & CL & 26 & F & R & Neoplasm \\
\hline
\end{tabular}

These are presented in tabular form(Table 1). In short, all the patients happened to be females. The right eye preponderated, while the ages ranged from 26 to 64 years (average 41 years). It is apparent that the provisional diagnosis was malignancy per se. Thus, it was left to microscopy to stamp the diagnosis of carcinoma in situ.

\section{Discussion}

Clearly, our local cohort was younger than the Argentinians [2]. In addition, whereas their sex presentation was equal, our own was curiously slanted to females. Concerning the study from Denmark [5], there was a mixture of squamous cell dysplasia, carcinoma in situ, and squamous carcinoma. Out of a total of 143 cases, carcinoma in situ came to 19 cases and squamous carcinoma to 29 cases, i.e., 1:1.5 ratio. The comparative figures for USA were 22 and 38 respectively, i.e., 1:1.7 [6]. Clearly, both are close.

Now, there are 51 cases of squamous carcinoma among the Igbos as against the five in-situ cases, i.e., 1:10.2 ratio. Therefore, the lesson is clear, namely, early presentation of eye malignancy is rare in the Igbo population. Indeed, it is hypothesized that this ratio should be applicable to any epidemiological research worldwide. Thus, in South Africa [7], such a comparison is possible, seeing that the information diversified the total cohorts in terms of (i) carcinoma in situ and (ii) squamous cell carcinoma, even though the background was the treatment of HIV infection. 


\section{Cancer Therapy \& Oncology International Journal}

\section{References}

1. Steinhorst U, von Donarus D (1990) Carcinoma in situ of the cornea. Ophthalmologica 200(2): 107-110

2. Crim N, Fornies-Paz ME, Monti R (2013) In situ carcinoma of the conjunctiva: Surgical excision associated with cryotherapy. Clin Ophthalmol 7: 1889-1893.

3. Macartney JC, Rollaston TP, Codling BW (1980) Use of a histopathology data pool for epidemiological analysis. J Clin Pathol 33(4): 351-353.

4. Basden GT (1966) Niger Ibos. Cass, London.
5. Ramberg I, Heegaard S, Prause JU, Sjö NC, Toft PB, et al. (2015) Squamous cell dysplasia and carcinoma of the conjunctiva. A nationwide, retrospective, epidemiological study of Danish patients. Acta Ophthalmol 93(7): 663-666.

6. Tunc M, Char DH, Crawford B, Miller $\mathrm{T}$ (1999) Intraepithelial and invasive squamous cell carcinoma of the conjunctiva: Analysis of 60 cases. Br J Ophthalmol 83(1): 98-103.

7. Lecuona K, Stannard C, Hart G, Rice J, Cook C, et al. (2015) The treatment of carcinoma in situ and squamous cell carcinoma of the conjunctiva with fractionated strontium-90 radiation in a population with a high prevalence of HIV. Br J Ophthalmol 99(9): 1158-1161.

\section{Your next submission with Juniper Publishers} will reach you the below assets

- Quality Editorial service

- Swift Peer Review

- Reprints availability

- E-prints Service

- Manuscript Podcast for convenient understanding

- Global attainment for your research

- Manuscript accessibility in different formats

( Pdf, E-pub, Full Text, Audio)

- Unceasing customer service

Track the below URL for one-step submission https://juniperpublishers.com/online-submission.php 